\title{
E-service Quality and Perceived Value as Predictors of Customer Loyalty towards Online Supermarkets
}

\author{
Minimol M. C. ${ }^{1}$ \\ ${ }^{1}$ Rajagiri Centre for Business Studies, Rajagiri College of Social Sciences (Autonomous), Rajagiri Valley, \\ Kakkanad, Kochi, Kerala, India \\ Correspondence: Minimol M. C. Tel: 98-4632-9021. E-mail: minimol@rajagiri.edu
}

Received: January 11, 2018

Accepted: January 23, 2018

Online Published: February 26, 2018

doi:10.5539/ass.v14n3p71

URL: https://doi.org/10.5539/ass.v14n3p71

\begin{abstract}
Service quality is progressively acknowledged as an important characteristic of e-commerce. As online comparison of the technical attributes of products is largely costless, viable, and easier than comparison of merchandises through traditional networks, service quality is perceived as the strategic element of customer loyalty in electronic commerce spectrum. A conceptual model explaining the correlation among e-service quality dimensions, customer's perceived value and loyalty towards online super markets is proposed and discussed in the present study. The research design adopted for the current study was descriptive in nature. The research approach used was field survey, by employing a structured questionnaire. Online survey method was adopted for data collection, so the data source is online shoppers in India. The study pinpointed that the four aspects of eservice quality, namely, fulfilment, system availability, efficiency and privacy positively influence the perceived value. It also disclosed that perceived value positively contributed to customer loyalty. The study results brought about the catalytic role of e-service quality and perceived value in online shopping framework. While designing websites of online supermarkets, the four pillars of electronic service quality needs to be focused on, considering their potential to promote customer loyalty to the store.
\end{abstract}

Keywords: E-service quality, perceived value, customer loyalty, online super market, virtual market place, website quality

\section{Introduction}

Even though service quality is an over researched subject in marketing academics over the last thirty years, application of the same concept in electronic commerce framework is somewhat recent. Juxtaposing the idea of virtual trading and the measurement of service quality offered by the customary settings, online service quality is better explained as the quality and the worth of online service contributions in the online market space by the customer's general evaluation and explanation (Santos, 2003). Indeed, Zeithaml et al. (2000; 2002) explained electronic service quality as the level up to which the platform expedite proficient and cost-effective purchase, and supply of goods and services. This definition is observed to be more popular and acceptable in the e-commerce spectrum, as the virtual platform is basically unique and different from that of the traditional market space. Traditional commerce, do not offer the customers to have all rudiments of the service, whereas in virtual scenario each element has a better chance to be appreciated by the customers. They can spend more time with the virtual retailer (Lee \& Lin, 2005). Moreover, the buying process is not directed by any sales executive and hence, the customers have to experience the whole process by themselves. So, customers are perceiving the e-service essentially as both a complete process as well as an outcome. Rowley (2006) comes out with a definition of e-service by concluding the opinion of many scholars in the subject area as a service, based on information and communication technology, including the supply of information, system support, the logistics and sharing of information. Electronic service are generally provided through electronic stores. Online supermarket or e-supermarket is a web-enabled system of retailing through which customers can order products and services. E-retailing is the online edition of traditional retail shop and is conceived as a virtual retail shop. Thus online super market talks about the virtual place of market offered by e-stores. This study, particularly focuses on online super markets, operating in India.

With rapid development and extensive application of the internet in the marketing tactics of firms, ensuring service quality in virtual space becomes a crucial problem for vendors in the e-commerce sector. Electronic service quality is turned out to be an important factor in deciding the destiny of e-commerce sector. Electronic 
retail industries face problems in fascinating the users. Unlike old-fashioned retail markets, e-retail store is characterized by the dearth of direct oral communication and direct individual supervision. Researchers recommend that building and expanding customer loyalty in virtual commerce framework is more strenuous than in conventional business setting (Chang, Wang, \& Yang, 2009). Loyalty of consumers results in re-purchase through the same supplier, if they guarantee satisfaction (Chang et al., 2009). Reliable customers often are central to the progress of businesses. In electronic commerce context, customers are having fewer chance to do repeat purchase through the same website, unless they experience the best value, even if they are satisfied. As an alternative to this, they will pursue other websites to find better value. It is just a question of single mouse click in virtual settings, hence it is crucial that firms realize how to build up and sustain loyalty in electronic retailing. The role of service quality in enhancing consumer satisfaction, consumer trust, and consumer loyalty is widely deliberated in many research papers. Retailers are quickly adapting cutting edge e-retail services through their web platforms. But, less number of studies are actually contributing to the explicit correlation between online service quality and customer loyalty in e-retail context. It is against this background, this study attempted to research and look into the link between these variables in Indian online supermarkets. E-service quality is observed to be a significant predictor of loyalty which is really essential for the progress and performance of businesses irrespective of its nature. In this study, e-service quality is conceived as a construct with four pillars such as privacy, efficiency, fulfilment and system availability as mentioned by Parasuraman, Zeithaml and Malhotra (2005). The study approach is quantitative in nature and is designed to answer the research question, what is the effect of electronic service quality on customer loyalty towards online super markets in India? The specific objectives pertinent to the study are to analyze the impact of four elements of e-service quality such as, system availability, efficiency, privacy, and fulfilment on perceived value and to find out how perceived value influences customer's loyalty towards online supermarkets.

\subsection{Literature Review}

E-service quality is largely conceived as general customer assessment, evaluation and judgments pertaining to the fineness and excellence of e-service delivery approach in the online markets (Lee \& Lin, 2005). Barnes and Vidgen (2002) has come out with five components of e-service quality - trust, design, usability, information, and empathy. Usability is concerned with the manifestation, user-friendliness, navigation, and the concept communicated to the end user. Design implies pleasing and artistic appearance. Information is about the pertinence of the information to the end user's requirements. Trust pinpoints the reputation and safety of transactions, while empathy is about message, society and personalization. Santos (2003) identified some predictors of e-service quality like appearance, ease of use, linkage, content, structure and layout, reliability, support, efficiency, communication, incentive and security. Wolfinbarger and Gilly (2003) found out four antecedents of e-quality including website design, fulfillment/reliability, security/privacy and customer service. Ribbnink, Van Riel, Liljander and Straukens (2004) came out with five antecedents of e-service quality namely, customization, ease of use, e-scape, assurance and responsiveness. Customers of e-services anticipate spontaneous feedback on demands, and also, when they recommend modifications. Security and privacy are significant concerns of e-service customers. Lee and Lin brought out (2005) five factors of e-service quality. Their dimensions include reliability, website design, trust, responsiveness and personalization. Parasuraman, Zeithaml and Malhotra (2005) argued that two distinctive measures should be adopted for assessing e-service quality, the general E-S-QUAL scale and the revised E-RecSQUAL. The basic E-S-QUAL scale consisted of four aspects: fulfillment, efficiency, privacy and system availability. Efficiency talks about the easiness and quickness of getting and operating the site. Fulfillment is regarding the extent, to which the site's assurance on delivery and availability of the particular item are satisfied. System availability denotes the prompt technical performance of the site. Privacy indicates the security offered by the site and the level to which it safeguards information about the customer. E-S-QUAL is important for a website's aggregate customer base. E-RecS-QUAL is designed as a subscale of the general E-S-QUAL and involves various things like managing service problems and queries. E-RecS-QUAL is relevant just to consumers having non-customary use of the sites. It deals with three quality elements, namely responsiveness, compensation, and contact. Responsiveness is about the effectiveness in handling issues and reverts through the site. Compensation denotes how the site recompense customers for predicaments. Contact is conceived as availability of help over telephone or through the customer care executives. Raman, Stephenaus, Alam and Kuppusamy (2008) recommended six components of e-service quality viz. ease of use, communication, reliability, customization, appearance and incentive. Swaid and Wigand (2009) brought out another set of electronic service quality dimensions - usability, reliability, information quality, assurance, responsiveness and personalization.

Farnaz Beheshti Zavareh et al., (2012) the concepts and theories regarding e service quality are simply based on 
consumer perceptions. They attempted to test whether, these perceptions translate well to countries like Iran, and whether it is possible to use e-service quality dimensions in Iranian Internet banking context. There is an enduring debate in the existing literature regarding the similarity and underlying difference between quality perceptions and satisfaction of customer in online service delivery context. Some studies established that explicit website e-services positively influence customer satisfaction towards the website and online procuring in the long run. Review on the evaluation of scales developed to gauge e-SQ, such as E-SERVQUAL, WebQual and eTailQ focused the need to authenticate the scales and to restructure the variables and constructs used, particularly in different service backgrounds and countries. The four dimensions of E-S-QUAL used in the study were system availability, fulfilment, efficiency, privacy and security with 22 items, constructed by Parasuraman et al. (2005) under the 4 dimensions.

In many of the research articles, published in the field of marketing, customer satisfaction, trust, and loyalty are found to be linked. Some papers investigated into the association among e-service quality and customer satisfaction while some other papers examined the effects of the service quality on customer satisfaction from different perspectives (Sheng \& Liu, 2010). Very few studies are conducted to investigate the direct association among e-service quality and customer loyalty (Ribbink, van Riel, Liljander, \& Streukens, 2004), particularly in online super markets the researcher found no such study. Some studies have been carried out on the same topic in other sectors. Thus, the researcher believes that it is useful and sensible to put an effort to establish the correlation among service quality dimensions and perceived value on customer loyalty for online supermarkets.

Hossain \& Hossain (2011) investigated the liaison among e-service quality and consumer loyalty in Swedish consumer electronic retail industry. E-service quality is proved to be a significant determinant of consumer loyalty which in turn is highly significant for the progress of any venture irrespective of the nature of the industry. The study was based on four central dimensions of e-service quality namely, reliability, responsiveness, ease of use, and security. They pointed out that all these dimensions of e-service quality have robust relationship with consumer loyalty which indicates that they have substantial influence on the loyalty of consumers in electronics retail industry. They pointed out that the customers attach highest priority to the organization of website contents and security of transaction. If the company organize the e-retailing website persuasively and guarantee security of transaction, the customers have more probability to show loyalty towards that organization. They also revealed that reliability is less important than the three other factors according to multiple regressions analysis result; though all the four factors found to be significant according to simple regression.

\section{Material and Methods}

The dominant methodology adopted for this study was descriptive in nature. The study is designed to be carried out through a field survey, by using structured questionnaire. Data collection was done through online survey method, so population is taken as online shoppers in India. The sample respondents were picked by using convenience sampling technique. As the exact size of population is unknown, a sample size that is representative, irrespective of the population size is taken for the study. As the research problem in the current study addresses the online super markets functioning in India, online shoppers of India who had ever purchased products through the internet forms part of the sample. 300 such online shoppers were selected, from the entire country, to constitute the sample. Thus, the sample for the current study was 300 online shoppers from different parts of India, including Kerala, Karnataka, Madhya Pradesh, Gujarat, New Delhi and Assam. Structural Equation Modelling was used for data analysis. The questionnaires were adapted from E-S-Qual scale of Parasuraman, Zeithaml and Malhotra (2005) and Marimon et al. (2010).

\subsection{Conceptual Model}

The theoretical model of the study is given in Figure 1.

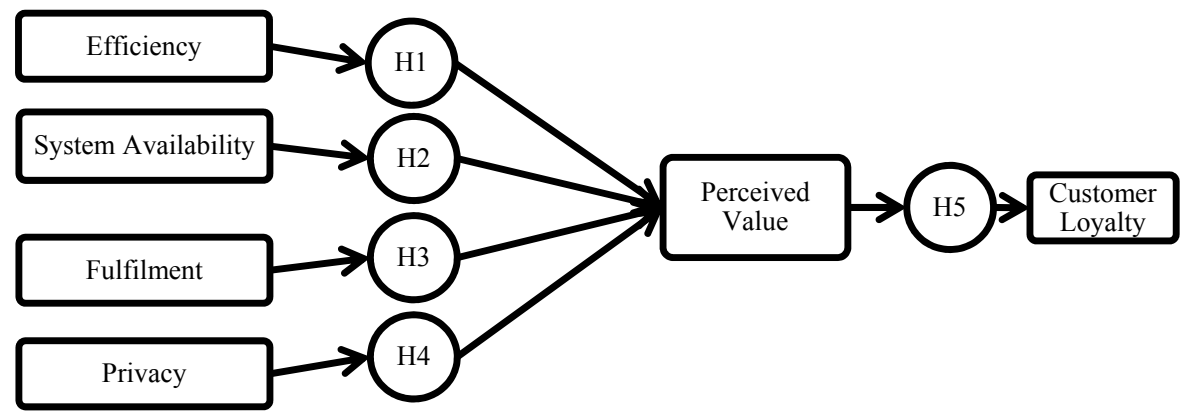

Figure 1. Conceptual Model 


\subsection{Research Hypotheses}

Five hypotheses were formulated for the present study such as:

- Efficiency positively contributes to perceived value.

- System availability positively contributes to perceived value.

- Fulfillment positively contributes to perceived value.

- Privacy positively contributes to perceived value.

- Perceived value positively contributes to customer loyalty towards online super market.

\section{Results}

To investigate into the relationship between the variables, and to test the research model, SEM based PLS analysis was used. The analysis results are given below.

Table 1. Descriptive Statistics

\begin{tabular}{ccccccc}
\hline & System Availability & Efficiency & Fulfilment & Perceived Value & Privacy & Customer Loyalty \\
\hline $\mathrm{N}$ & 300 & 300 & 300 & 300 & 300 & 300 \\
Mean & 3.8 & 3.8 & 3.8 & 3.6 & 3.8 & 3.8 \\
Standard Deviation & 0.820 & 0.244 & 0.536 & 0.766 & 0.587 & 0.693 \\
\hline
\end{tabular}

Source: PLS Analysis

From the mean scores of the constructs listed above, it can be observed that, on an average, the participants responded positively to the research constructs (the averages are greater than 3). It is also evident that the mean scores for efficiency, system availability, fulfilment, privacy and customer loyalty are 3.8 and for perceived value it is 3.6 , this lies between the options "Neutral" and "Agree" (which is relevant to the ratings 3 and 4 on the Likert scale ) but more lenient towards the "Agree" option.

Table 2. General Results of SEM Analysis - Model Fit

\begin{tabular}{cc}
\hline Model Fit Indices & P values \\
\hline $\mathrm{APC}=0.45, \mathrm{P}<0.001$ & Less than 0.001 \\
$\mathrm{ARS}=0.63, \mathrm{P}<0.001$ & Less than 0.001 \\
$\mathrm{AVIF}($ Good if $<5)$ & 3.12 \\
\hline
\end{tabular}

Source: PLS Analysis

The general results regarding the model fit are given in the above Table 2. Both APC and ARS p values are less than 0.001 and Average variance extracted (3.12) is less than 5. Hence, it is concluded that the model is statistically reliable for analysis.

Table 3. Latent Variable Coefficients

\begin{tabular}{ccccccc}
\hline & $\begin{array}{c}\text { Perceived } \\
\text { Value }\end{array}$ & $\begin{array}{c}\text { Customer } \\
\text { loyalty }\end{array}$ & Efficiency & $\begin{array}{c}\text { System } \\
\text { availability }\end{array}$ & Fulfilment & Privacy \\
\hline R - Squared & 0.79 & 0.95 & & & & \\
Adj. R - Squared & 0.73 & 0.97 & & & & \\
$\quad$ Composite & 0.86 & 0.79 & 0.92 & 0.88 & 0.92 & 0.89 \\
Reliability. & 0.72 & 0.85 & 0.91 & 0.85 & 0.89 & 0.80 \\
Cronbach's Alpha & 0.65 & 0.67 & 0.74 & 0.86 & 0.63 & 0.66 \\
AVE & 0.66 & 0.86 & & & & \\
Q - Squared & & & & &
\end{tabular}

Source: PLS Analysis

\subsection{Reliability of the Constructs}

A construct is said to be reliable if all the statements about the variable in the questionnaire are understood in the same way by different respondents. Fornell \& Larcker, 1981; Nunnally \& Bernstein, 1994, are of the opinion that both the composite reliability and Cronbach's alpha should be at least equal to or higher than 0.70 , for a 
measurement instrument to be considered as reliable. Field (2005), argued that a Cronbach's alpha value between 0.70 and 0.80 are acceptable. Table 3 given above, revealed that the composite reliability coefficients of the variables used in the study ranged from 0.76 to 0.92 and the Cronbach's alpha coefficients ranged between 0.72 and 0.92 . It was so concluded that the instrument has acceptable level of reliability.

\subsection{Path Coefficients and P values}

The estimated model with path coefficients and corresponding $\mathrm{P}$ values are provided in Table 4.

Table 4. Pathways and Beta Values of the constructs

\begin{tabular}{cc}
\hline Pathways & Beta Value \\
\hline Efficiency $\rightarrow$ Perceived value & 0.38 \\
System availability $\rightarrow$ Perceived value & 0.24 \\
Fulfilment $\rightarrow$ Perceived value & 0.23 \\
Privacy $\rightarrow$ Perceived value & 0.12 \\
Perceived value $\rightarrow$ Customer loyalty & 0.58 \\
\hline
\end{tabular}

Source: PLS Analysis

Efficiency is positively related $(\beta=0.38)$ to perceived value, which indicates that as the efficiency increases, customer's perceived value towards the website also increases. It also indicates that one unit change in the efficiency of the website would change perceived value by 0.38 units. System availability is also positively related $(\beta=0.24)$ to perceived value, which indicates that as the system availability increases, perceived value also increases, revealing that one unit change in the system availability would increase perceived value by 0.24 units. In similar lines both fulfilment and privacy have positive relationships with perceived value $(\beta=0.23$ and 0.12 respectively). Perceived value do have a positive association with customer loyalty $(\beta=0.58)$, pointing out a 0.58 unit change in customer liability when there is one unit change in perceived value.

\subsection{Research Model}

The derived model with path coefficients as well as corresponding $\mathrm{P}$ values are provided in Figure 2.E-service quality dimensions together explained 55 percentage of the variation in perceived value. $P$ values are lesser than 0.05 , hence, it can be inferred that the linkage between E-service quality and perceived value is statistically significant. All the e-service quality aspects (efficiency, system availability, fulfilment and privacy) have got positive relationships $(\beta=0.38,0.24,0.23$ and 0.12$)$ with perceived value, indicating that increase in efficiency of the website, system availability, fulfilment and privacy offered by the website increases the perceived value of the customers. The model also indicates that perceived value accounts for almost 34 per cent variation in customer loyalty. A one unit change in perceived value accounts for nearly 0.58 units change in customer loyalty. Beta value is positive $(\beta=0.58)$ and $P$ value is less than 0.01 , hence it can be inferred that the relationship between perceived value and customer loyalty is statistically significant and positive.

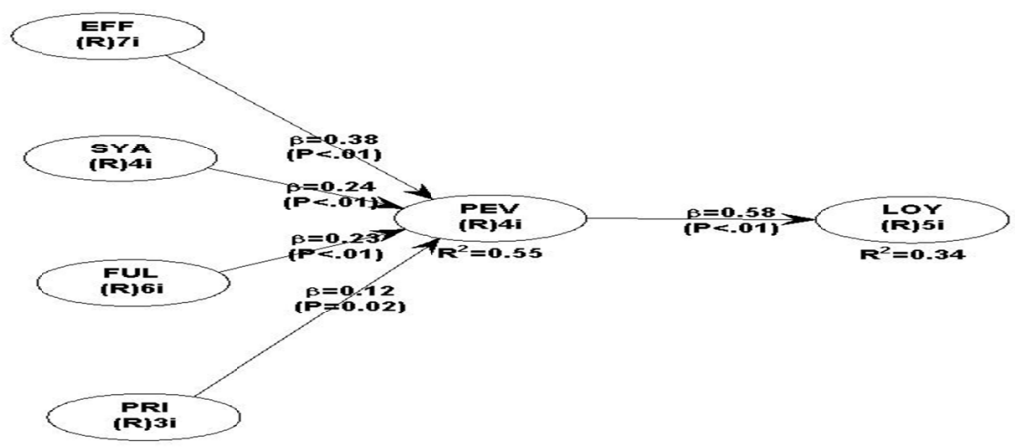

Source PLS Analysis

Figure 2. Research Model

All the structural models were examined to test the hypotheses developed for the study. There were 5 hypotheses to test the various relationships mentioned in the research model, all of them were supported. The outcomes of hypotheses testing are given in Table 5 . 
Table 5. Details of Hypotheses Testing

\begin{tabular}{cccccc}
\hline $\begin{array}{c}\text { Sl. } \\
\text { No. }\end{array}$ & $\begin{array}{c}\text { Hypothesis } \\
\text { No. }\end{array}$ & Hypothesis & $\begin{array}{c}\text { Path } \\
\text { Coefficient }\end{array}$ & $\begin{array}{c}\mathrm{P} \\
\text { Value }\end{array}$ & Result \\
\hline 1. & H1 & Efficiency positively contributes to perceived value. & $\beta=0.38$ & $\mathrm{P}<0.01$ & $\sqrt{ }$ \\
2. & H2 & System availability positively contributes to perceived \\
value & $\beta=0.24$ & $\mathrm{P}<0.01$ & $\sqrt{ }$ \\
3. & H3 & Fulfillment positively contributes to perceived value. & $\beta=0.23$ & $\mathrm{P}<0.01$ & $\sqrt{ }$ \\
4. & H4 & Privacy positively contributes to perceived value. & $\beta=0.12$ & $\mathrm{P}<0.01$ & $\sqrt{ }$ \\
5. & H5 & $\begin{array}{c}\text { Perceived value positively contributes to customer } \\
\text { loyalty towards online super market. }\end{array}$ & $\beta=0.58$ & $\mathrm{P}<0.01$ & $\sqrt{ }$ \\
\hline
\end{tabular}

Source: Prepared by the author

$\sqrt{ }$ indicates hypothesis supported

The current study found that efficiency, system availability and fulfilment do have a statistically significant effect on perceived value, thus confirming H1, H2 and H3. Parasuraman et al. (2005) also pointed out that these dimensions are critical contributors to what customers' perceived as value. The present analysis also pointed out that privacy had a substantial effect on perceived value, thus confirming H4. Similarly, Parasuraman et al. (2005) found that efficiency and fulfilment were the most critical (and equally important) dimensions of website service quality. The study also revealed that customer's perceived value has got a statistically significant and positive relationship with customer loyalty towards online super markets, thus confirming H5.

\section{Discussion}

The study revealed that there exists a statistically significant and direct positive linkage between e-service quality and perceived value. E-service quality dimensions together contributes to more than half of the variation in perceived value. Perceived value explains more than one-third variation in customer loyalty. The results of the study revealed the importance of e-service quality and perceived value in online supermarkets. While designing websites of online supermarkets, the four aspects of e-service quality needs to be focused on, considering their potential to influence customer loyalty towards the online store. The study also analyzed the potential contribution of perceived value to customer loyalty and concluded that customer's perceived value considerably influences customer loyalty. The researcher also tried to develop a model explaining the link among e-service quality, perceived value and customer loyalty towards virtual supermarkets. These findings are conforming to the outcomes of earlier studies conducted by Parasuraman et al. in 2005. The overall findings of the study brought about the significant contribution of e-service quality and perceived value to the customer loyalty towards the online supermarket.

\section{Conclusion}

The result of the current study signals that e-service quality and perceived value matters in describing the customer's loyalty in the context of online supermarket. The findings of the study will help the practitioners, academicians, students, researchers and consultant trainers to identify new means of designing the website, considering the relationships revealed by the study. It will also help them to focus on novel ways to increase the efficiency, system availability, fulfilment and privacy of the website and to bring about tailor-made platforms to the online supermarkets. It is also important to have an understanding of the elements of e-service quality and perceived value which ultimately influences customer loyalty in electronic platform, which ultimately provide a competitive edge to the online supermarkets. The present study has demonstrated signals of association among e-service quality dimensions, perceived value and customer loyalty to online supermarkets and has confirmed that the four elements of the e-service quality are positively contributing to perceived value, which in turn has got a positive and statistically significant relation with customer loyalty towards online supermarkets. . The study findings are thus generally in accordance with the findings of earlier researchers in the field who have pinpointed the effectiveness of these constructs to arrive at customer loyalty. More specifically, the efficiency component has been proved to have an important impact on customer loyalty, while perceived value is adjudged as mediator in the relationship.

\section{References}

Barnes, S. (2006). E-commerce and V-business. Digital enterprise in the twenty-first century. Oxford: 
Butterworth-Heinemann.

Barnes, S. J., \& Vidgen, R. T. (2002). An Integrative Approach to the Assessment of E-Commerce Quality. Journal of Electronic Commerce Research, 3(3), 114 -127.

Chang, H. H., Wang, Y., \& Yang, W. (2009). Impact of e-service quality, customer satisfaction and loyalty on e-marketing: moderating effect of perceived value. Total Quality Management \& Business Excellence, 20(4), 423-443. https://doi.org/10.1080/14783360902781923

Farnaz, B. Z. et al. (2012). E-service quality dimensions and their effects on e-customer satisfaction in internet banking services, Procedia - Social and Behavioral Sciences, 40, 441-445. https://doi.org/10.1016/j.sbspro.2012.03.213

Field, A. (2005). Reliability analysis. Discovering Statistics Using spss (2nd ed.). Sage, London.

Fornell, C., \& Larcker, D. F. (1981). Evaluating Structural Equation Models with Unobservable Variables and Measurement Error. Journal of Marketing Research, 18(1), 39-50. https://doi.org/10.2307/3151312

Hossain, M. Y., \& Hossain, M. (2011). E-service quality and consumer loyalty: a study on consumer electronic retail industry. Umea School of Business, Master Thesis. https://doi.org/10.1108/09604520310476490

Kim, M., Kim, J., \& Lennon, S. (2006). Online service attributes available on apparel retail web sites: an E-S-QUAL approach. Managing Service $\quad$ Quality, https://doi.org/10.1108/09604520610639964

Lee, G. G., \& Lin, H. F. (2005). Customer perceptions of e-service quality in online shopping. International Journal of Retail \& Distribution Management, $33(2), \quad$ 161-176. https://doi.org/10.1108/09590550510581485

Marimon, F., Vidgen, R., Barnes, S., \& Cristobal, E. (2010).Purchasing behavior in an online supermarket. International Journal of Market Research, 52(1), 1-28.

Nunnally, J. C., \& Bernstein, I. H. (1994). Psychometric Theory. New York: McGraw-Hill.

Parasuraman, A., Zeithaml, V., \& Malhotra, A. (2005). E-S-Qual: a multiple-item scale for assessing electronic service quality. Journal of Service Research, 7(3), 213-233. https://doi.org/10.1177/1094670504271156

Raman, M., Stehenaus, R., Alam, N. \&Kuppusamy, M. (2008). Information technology in Malaysia: e-Service quality and uptake of internet banking. Journal of Internet Banking and Commerce, 13(2), 1-18.

Ribbink, D., Van Riel, A., \& Streukens, S. (2004). Comfort your online customer: quality, trust and loyalty on the internet. Managing Service Quality, 14(6), 446-456. https://doi.org/10.1108/09604520410569784

Rowley, J. (2006). An analysis of the e-service literature: Towards a research agenda. Internet Research, 16(3), 339-359. https://doi.org/10.1108/10662240610673736

Santos, J. (2003). E-service quality: a model of virtual service quality dimensions. Managing Service Quality: An International Journal, 13(3), 233-246. https://doi.org/10.1108/09604520310476490

Swaid, S. I., \& Wigand, R. T. (2009). Measuring the quality of e-service: scale development and initial validation. Journal of Electronic Commerce Research, 10(1), 13-28.

Wolfinbarger, M., \& Gilly, M. G. (2003). ETailQ: dimensionalizing, Measuring and Predicting Tail Quality. Journal of Retailing, 79, 183-198. https://doi.org/10.1016/S0022-4359(03)00034-4

Zeithaml, V. A., Parasuraman, A., \& Malhotra, A. (2000). A Conceptual Framework for Understanding E-Service Quality: Implications for Future Research and Managerial Practice (pp. 1-49). Working Paper, Marketing Science Institute, Cambridge, MA.

Zeithaml, V. A., Parasuraman, A., \& Malhotra, A. (2002). Service Quality Delivery Thought Websites: A Critical Review of Extant Knowledge. Journal of the Academy of Marketing Science, 30(4), 362-375. https://doi.org/10.1177/009207002236911

\section{Copyrights}

Copyright for this article is retained by the author(s), with first publication rights granted to the journal.

This is an open-access article distributed under the terms and conditions of the Creative Commons Attribution license (http://creativecommons.org/licenses/by/4.0/). 